\title{
Influence of E1 Niño and La Niña phenomena on seasonality of the relative frequency of rainfall in southern Amazonas mesoregion
}

\section{Influência dos fenômenos El Niño e La Niña na sazonalidade da frequência relativa da precipitação da mesorregião sul do Amazonas}

\author{
Altemar Lopes Pedreira Junior ${ }^{1}$ (D), Carlos Alexandre Santos Querino ${ }^{2}$ (D), Marcelo Sacardi Biudes ${ }^{1}$ (D), \\ Nadja Gomes Machado ${ }^{3}$ (D), Luiz Octavio Fabricio dos Santos ${ }^{1}$ (D) \& Israel Oliveira Ivo ${ }^{1}$ (D) \\ ${ }^{1}$ Universidade Federal de Mato Grosso, Cuiabá, MT, Brasil \\ ${ }^{2}$ Universidade Federal do Amazonas, Humaitá, AM, Brasil \\ ${ }^{3}$ Instituto Federal de Mato Grosso, Cuiabá, MT, Brasil \\ E-mails: altemarjunior@fisica.ufmt.br(ALPJ), carlosquerino@ufam.edu.br (CASQ), marcelo@fisica.ufmt.br (MSB), \\ nadja.machado@blv.ifmt.edu.br (NGM), luizoctavio@fisica.ufmt.br (LOFS), israel@fisica.ufmt.br (IOI)
}

\begin{abstract}
The global and Amazon climate change, mainly in rainfall, due to the El Niño and La Ninã phenomena. The objective of this study was to analyze the relative frequency (RF) of rainfall, in different periods of the day, during occurrences of El Niño, La Niña events and neutrality condition. The research was carried out in the Southern mesoregion of the state of Amazonas (Apuí, Boca do Acre, Lábrea, Manicoré and Humaitá). Data were analyzed by the Spiegel’s method. The rainfall data were obtained from the Global Land Data Assimilation database from January 1st, 2000 to December 31st, 2018. Data were made available every three hours and integrated into six hours. RF of rainfall was higher in the afternoon in La Niña, Neutro and El Niño years in all municipalities. The RF in La Niña year was higher than during El Niño. The RF during the Neutral year was higher than during El Niño in Apuí and Boca do Acre, and had no difference in Lábrea, Manicoré and Humaitá. The rainfall in the southern Amazon mesoregion was more frequent during the afternoon.
\end{abstract}

Keywords: Amazon; ENSO; GLDAS.

\section{RESUMO}

O clima global e amazônico sofre alterações, principalmente na precipitação, em decorrência dos fenômenos El Niño e La Ninã. O objetivo deste trabalho foi analisar a frequência relativa da precipitação, em diferentes períodos do dia, durante ocorrências de eventos de El Niño, La Niña e em condição de neutralidade. A pesquisa foi realizada na mesorregião Sul do estado do Amazonas (Apuí, Boca do Acre, Lábrea, Manicoré e Humaitá). Os dados foram analisados pelo método proposto por Spiegel. Os dados foram obtidos a partir da base de dados da Global Land Data Assimilation (01/01/2000 a 31/12/2018). Os dados foram disponibilizados a cada três horas e integralizados em seis horas. A frequência relativa da precipitação foi maior no período da tarde nos anos de La Niña, Neutro e El Niño em todos os municípios. Houve uma superioridade da frequência relativa durante os anos de ocorrência de eventos La Niña quando comparados ao El Niño. Em Apuí e Boca do Acre ocorreu uma superioridade na quantidade de eventos durante o ano Neutro em relação ao El Niño, enquanto em Lábrea, Manicoré e Humaitá não houve mudança. Por fim, a precipitação nos municípios da mesorregião Sul do Amazonas é frequente durante os períodos da tarde.

Palavras-chave: Amazônia; ENOS; GLDAS. 


\section{INTRODUCTION}

The Amazon has one of the longest hot and humid areas on the planet with rainfall rates higher than $2000 \mathrm{~mm}^{2} \mathrm{ano}^{-1}$ (Marengo \& Nobre, 2009; Limberger \& Silva, 2016). On the other hand, the southern portion of the state of Amazonas has average by $2300 \mathrm{~mm}^{2} \mathrm{no}^{-1}$ (Instituto Nacional de Meteorologia, 2009). These high volumes of rainfall in the South Amazon mesoregion are due to general atmospheric circulation, latitudinal location and the dynamics of various meteorological systems (Franca \& Mendonça, 2016). However, the rainfall patterns and local climate of the Southern Amazon may be affected due to increased deforestation of large areas (Fearnside, 2005; Artaxo et al., 2009) and changes in the dynamics of ocean-atmosphere interaction, such as those caused by El Niño Southern Oscillation (ENSO) (Ferreira et al., 2013).

ENSO are positive (El Niño) or negative (La Niña) anomalies in Pacific Ocean Surface Temperature (TSM) and cause fluctuations in atmospheric pressure at sea level (Tedeschi et al., 2015). This fluctuation of atmospheric pressure provides variation in atmospheric circulation, and consequently droughts, floods and global climate variation due to intensification of extreme events and change in the frequency of rainfall events ( $\mathrm{Li}$ et al., 2011; Ferreira et al., 2013; Tanaka et al., 2014; Jacques-Coper \& Garreaud, 2015; Sun et al., 2015; Marengo \& Espinoza, 2016; Shimizu et al., 2017; Rao \& Ren, 2017).

Relative Frequency (RF) of rainfall studies provide important information and provide a better understanding of rainfall variability and distribution (Burauskaite-Harju et al., 2012). RF allows to determine the standard period of rainfall throughout the day for a given region, which is not found in analyzes of daily, monthly or annual average totals (Brown et al., 2018). This information also serves as support for studies on soil impacts, runoff, agricultural planning, degradation and water availability (Westra et al., 2013; Joshi et al., 2019).

Daytime variation of rainfall in the Amazon basin has been studied by several authors in recent years, such as Cutrim et al. (2000), Angelis et al. (2004), Funatsu et al. (2012), Santos Neto et al. (2014), Tanaka et al. (2014), Costa et al. (2018) and Pedreira Junior et al. (2018). These studies have shown differences in the frequency of rain events in several sectors of the basin. However, studies on the influence of ENSO phenomena on rainfall RF seasonality in the southern Amazon mesoregion are limited or even nonexistent.

The lack of such studies in the Amazon basin is due to the scarcity and heterogeneity of weather stations, especially regarding data access and the high number of failures (Ronchail et al., 2002; Debortoli et al., 2015; Santos et al., 2019). Data estimated by the Global Land Data Assimilation System (GLDAS) enable studies on the spatiotemporal variation of meteorological variables, as this product was developed from advanced land surface modeling and data assimilation methods (Rodell et al., 2004). GLDAS product data are accurate by integrating observation data with numerical models and reanalysis (Rodell et al., 2004; Mei \& Wang, 2012).

Due to the importance of knowing the temporal distribution of precipitation, as well as the influence of ENSO on precipitation in southern Amazonas, it is necessary to evaluate the RF pattern of precipitation in this region. Understanding the seasonal pattern and at which time of day precipitation occurs contributes to solving various problems in urban planning, water resources planning and agricultural planning in the region. Thus, the objective of this work was to analyze the relative frequency of precipitation in the southern Amazon mesoregion in years of neutrality and occurrence of El Niño and La Niña events.

\section{MATERIAL AND METHODS}

\section{Study area}

The rainfall data were estimated in the municipalities of Apuí (AP; $7.20^{\circ} \mathrm{S}, 59.88^{\circ} \mathrm{W}$ and $135 \mathrm{~m}$ ), Boca do Acre (BA; $8.77^{\circ} \mathrm{S}, 67.33^{\circ} \mathrm{W}$ and $\left.116 \mathrm{~m}\right)$, Lábrea (LB; $7.26^{\circ} \mathrm{S}, 64.78^{\circ} \mathrm{W}$ and $75 \mathrm{~m}$ ), Manicoré (MN; $5.78^{\circ} \mathrm{S}, 61.28^{\circ} \mathrm{W}$ and $\left.45 \mathrm{~m}\right)$ and Humaitá (HT; $7.55^{\circ} \mathrm{S}, 63.07^{\circ} \mathrm{W}$ and $58 \mathrm{~m}$ ) which are located in the southern mesoregion of Amazonas State (Figure 1). The climate of the region is classified as humid (AP, BA, HT e LB) and super humid $(\mathrm{MN})$, with moderate or no water deficiency in winter, and three distinct periods: wet (October to April), transition (May and September) and dry (June to August) (Martins, 2019).

\section{Rainfall data}

Rainfall data of $0.2 \mathrm{~mm}$ or greater between January 1st, 2000 and December 31st, 2018 (19 years) of the Global Land Data Assimilation (GLDAS_NOAH025_3H_v2.1) product were obtained of National Aeronautics and Space Administration (2019). This product provides rainfall on a spatial scale of $0.25^{\circ}$ and 3 hour of temporal resolution.

Rainfall time has been converted to local time (UTC/GMT-4). Subsequently, data were tabulated according to the total number of rainfall events recorded by the number of events occurring for each period of the day, considering Dawn (02h00 and 05h00), Morning (08h00 and 11h00), Afternoon (14h00 and 17h00) and Night (20h00 and 23h00).

The years of neutrality (January 1st, 2013 to December 31st, 2013), El Niño events (January 1st, 2015 to December 31st, 2015) and La Niña events (January 1st, 2000 to December 31st, 2000) were defined according to the Climate Prediction Center (National Weather Service, 2019). These years were chosen because they presented anomalies over twelve consecutive months.

\section{Analysis data}

Data were analyzed based on Relative Frequency (RF\%) of rainfall (Spiegel, 1972) (Equation 1). Subsequently, data were compared between the different periods of the day, seasons (summer, autumn, winter, and spring, or wet and dry).

$$
\mathrm{RF}(\%)=\frac{\mathrm{F}(6 \mathrm{~h})}{\mathrm{F}(\mathrm{n})} \times 100
$$

where $\mathrm{F}(6 \mathrm{~h})$ is a number of events every three hours later integrated into six hours (period of the day); $\mathrm{F}(\mathrm{n})$ the number of events during the day throughout the analyzed period. 


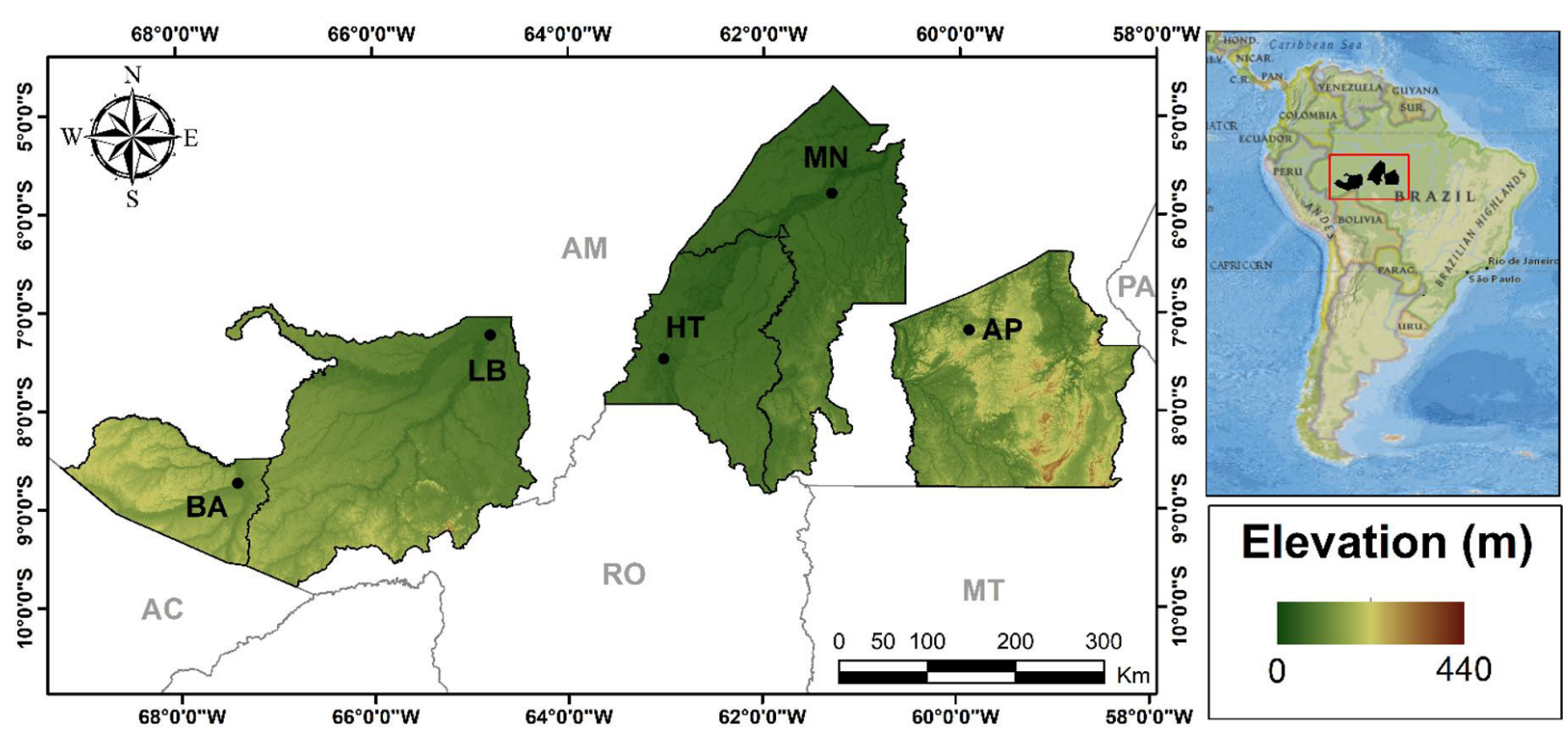

Figure 1. Location of municipalities of Apuí (AP), Boca do Acre (BA), Lábrea (LB), Manicoré (MN) and Humaitá (HT) in the southern mesoregion of the state of Amazonas, Brazil.

\section{RESULTS AND DISCUSSION}

Monthly rainfall in Apuí (AP) was higher than in other locations during the wet (Figure 2). It was caused by meteorological systems such as the South Atlantic convergence zone (SACZ), Instability Line (IL), Bolivian high (BH), Frontal systems (colds), and mainly because it is located at higher altitudes (Martins et al., 2018).

SACZ is defined as a cloud band that extends from the Amazon to the southeast of the country, resulting from the interaction between various meteorological systems and provides a prolonged period of frequent and heavy rain (Pedreira Junior et al., 2018). ILs form on the Atlantic coast of the Amazon and move west, causing precipitation in the region (Loureiro et al., 2014). BH is a high atmospheric anticyclone resulting from the marked release of latent heat associated with intense convection in the Bolivian highland region (Franca \& Mendonça, 2016). The frontal systems reach the southern Amazon and reach low latitudes, causing precipitation and temperature drop (Santos Neto et al., 2014).

Rainfall in Manicoré (MN) had a greater disparity than other location during the dry season (Figure 2). This disparity was due to its greater proximity to the Equator which receives more solar radiation and favors the transport of latent heat and humidity (Martins, 2019), since 35\% of the rain volume comes from local water steam (Satyamurty et al., 2012). In addition, Manicoré which is at $5^{\circ}$ latitude receives more influence from the Inter Tropical Convergence Zone (ITCZ) than other locations. During this period, the ITCZ is positioned further south, and along with the IL spread inland, providing greater rainfall volumes compared to other locations (Amanajás \& Braga, 2012).

A total of 41.663 rainfall events were recorded for all municipalities analyzed during the summer. This significant number of rainfall events occur because the summer coincides

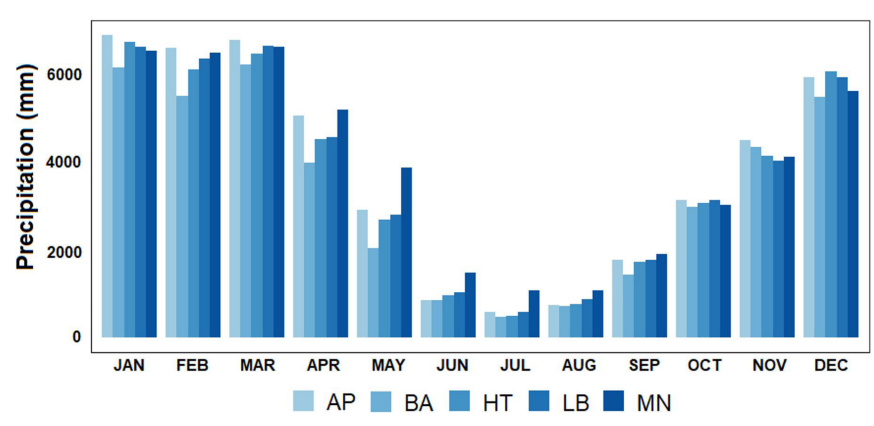

Figure 2. Monthly accumulated rainfall in Apuí (AP), Boca do Acre (BA), Humaitá (HT), Lábrea (LB) and Manicoré (MN) from January 2000 to December 2018.

with the region's wet season, which extends from October to March, characterized by the performance of meteorological systems (SACZ, ITCZ, BH and Frontal systems), as well as, by the largest amount of radiation emitted to the Southern Hemisphere, which causes intense convective activity over the region (Pedreira Junior et al., 2018).

The relative frequency (RF) of rainfall was higher in the afternoon $(\mathrm{AP}=36 \%, \mathrm{BA}=27 \%, \mathrm{LB}=28 \%, \mathrm{MN}=27 \%$ and $\mathrm{HT}=29 \%$ ) in all locations during summer (Figure 3). It is a result of the intense convective activity that acts over the entire Amazon region, in which part of the energy for rain formation is generated by the surface latent heat flux (Carvalho et al., 2012). The lowest RFs were recorded throughout the morning and morning in all location (Figure 3).

A total of 28.683 rainfall events in fall were concentrated in the afternoon $(\mathrm{AP}=40 \%, \mathrm{BA}=28 \%, \mathrm{LB}=29 \%, \mathrm{MN}=34 \%$ and $\mathrm{HT}=33 \%$ ) in all locations (Figure 3). However, the rains in fall were less present during dawn ( $\mathrm{AP}=14 \%, \mathrm{LB}=23 \% \mathrm{e}$ $\mathrm{HT}=20 \%)$ and morning $(\mathrm{BA}=23 \%$ e $\mathrm{MN}=18 \%)($ Figure 3$)$. 


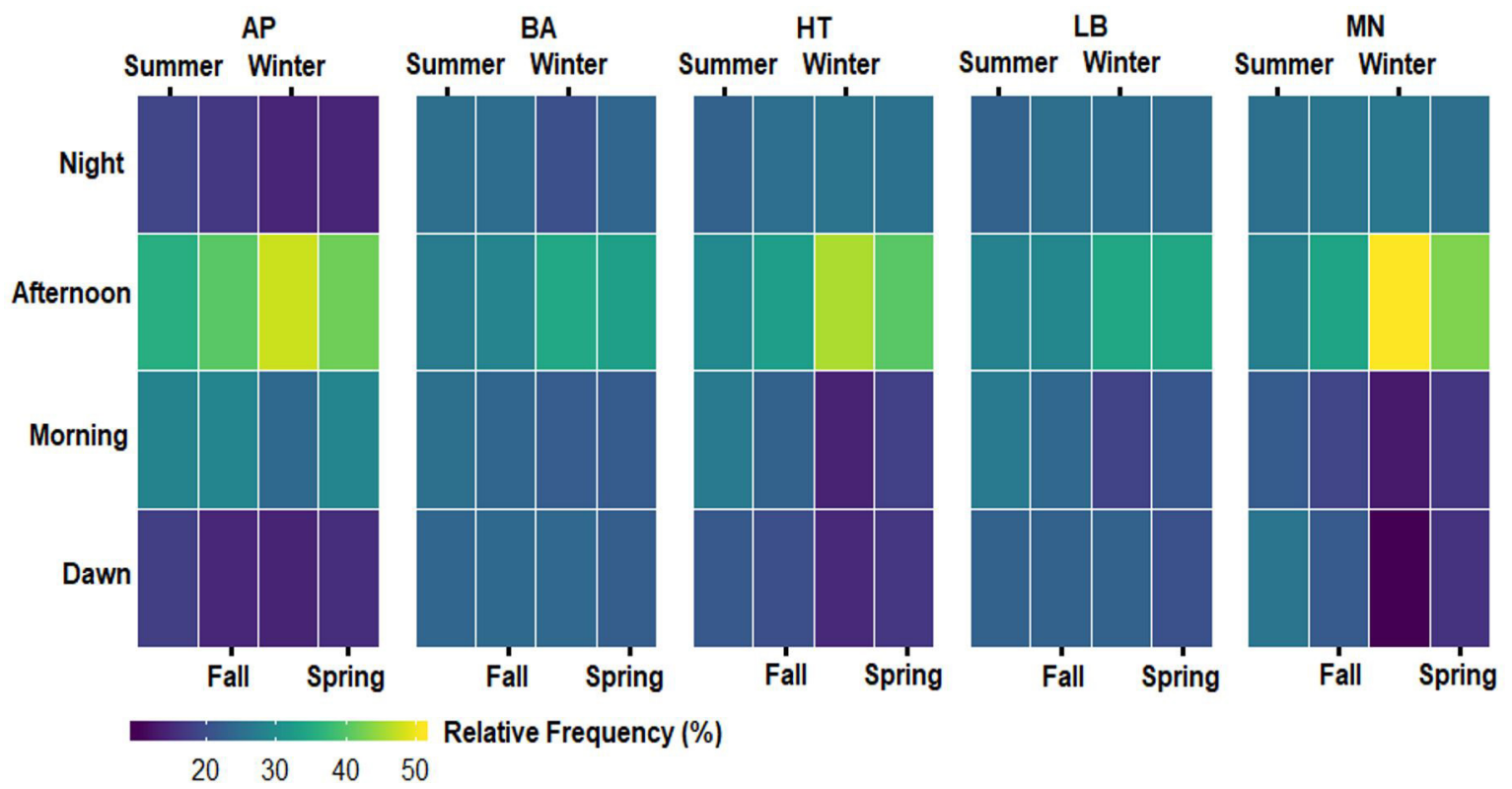

Figure 3. Relative Frequency (\%) of rainfall on different periods of the day in the summer, fall, winter and spring seasons in Apuí (AP), Boca do Acre (BA), Humaitá (HT), Lábrea (LB) and Manicoré (MN).

Only 9.398 of rainfall events occurred in winter. This small number of events during winter is due to occurrence of the dry period of the region (Santos Neto et al., 2014). There was a predominance of afternoon rainfall events in all location, ranging from $34 \%$ to $51 \%$. The second highest RF was observed at night in $\mathrm{LB}(24 \%), \mathrm{MN}(26 \%)$ and HT (25\%), and in the morning in AP $(24 \%)$ and at dawn in BA (24\%). The lowest RFs were observed at dawn in $\mathrm{AP}(14 \%)$ and $\mathrm{MN}(10 \%)$, in the morning in $\mathrm{LB}(18 \%)$ and HT (14\%) and at night in BA (20\%) (Figure 3).

The circulation of the lower troposphere during the dry season is transferred north of the equatorial cavity, favoring the movement of the Hadley cell to the Amazon. However, the low atmospheric runoff (between 925 and $700 \mathrm{hPa}$ ) provides moisture conduction in the southern Amazon throughout this season, which ensures optimal conditions for afternoon convection, justifying the discrepancy from the other day times (Marengo \& Nobre, 2009; Santos Neto et al., 2014). In addition, it is common for cold fronts to enter the southern Amazon during this season, causing precipitation and a decrease in air temperature (Santos Neto et al., 2014).

A total of 23.563 rainfall events were recorded in spring. The RF in the afternoon in spring ranged from $33 \%$ to $43 \%$ in all locations, followed by the RF at night in BA (23\%), LB (24\%), MN $(25 \%)$ and $\mathrm{HT}(25 \%)$ and in the morning in AP $(28 \%)$. The lowest RFs occurred at dawn in LB (20\%), MN (16\%) and HT (16\%), at night in AP (14\%) and in the morning in BA (22\%) (Figure 3). This pattern of RF in is due to the onset of the rainy season in the southern Amazon region, which is influenced by intense convective activity and the SACZ, frontal systems incursions and the beginning of the Monsoon Systems in South America (MSSA) which generates deep convection (Rolim et al., 2006).

The rainfall events during the wet season were well distributed throughout the day (Figure 4A). The high RFs during year with neutrality occurred in the afternoon in AP (44\%), HT (38\%) and $\mathrm{MN}(43 \%)$. The high RFs during El Niño year occurred in the afternoon in $\mathrm{BA}(29 \%)$ and $\mathrm{LB}(34 \%)$. As the rainy season coincides with the summer season and part of the spring, high precipitation occurs under the influence of SACZ and MSSA (Carvalho et al., 2012). However, the rainfall events during the dry season occurred predominantly in the afternoon in Neutral year in AP (48\%), HT (53\%), LB (43\%) and MN (58\%) and in La Ninã year in BA (37\%) (Figure 4B). In the dry period, precipitation events are associated with cold fronts, which contributes to modify the dynamics of the atmosphere by changing the stability condition to instability during this period (Pedreira Junior et al., 2018).

The RF was higher during La Niña year in all location ( $42 \%$ to $46 \%$ ), while the RF during neutral and El Niño years was similar (25\% to $29 \%$ ). The RF during Neutral year was higher than El Niño year in AP and BA. However, the RF during El Niño year was higher than Neutral year in LB, MN and HT (Figure 5).

The RF in La Niña year was more distributed throughout the day (Figure 6). During this period, there is a predominance of upward atmospheric circulation in the equatorial Walker/Hadley cell regions, which strengthen the ITCZ, and consequently, result in greater rainfall events throughout the day (Souza et al., 2005).

The RF in Neutral year was predominating in the afternoon (37\%), followed by the RF in the morning (26\%), and the lowest $\mathrm{RF}$ was found at night and at dawn (18\%) (Figure 6). Neutrality indicates that there were no anomalies on Pacific Ocean TSM, with the lowest water temperature near the west coast of South America, and highest near the Australian continent and the Indonesian region (Centro de Previsão de Tempo e Estudos Climáticos, 2015).

The RF in El Niño year higher in the afternoon (34\%) and in the morning $(29 \%)$ and was lower at night and at dawn $(18 \%)$ (Figure 6). During El Niño events, the downward 
movement of Walker's cell shifts over the Amazon and inhibit cloud formation and, consequently, convection. Thus, trade winds are much weaker, and moisture transport from the Atlantic Ocean to the Amazon region is reduced (Souza \&
Ambrizzi, 2002; Wang, 2002). In addition, during this period the Intertropical Convergence Zone (ITCZ) is positioned further North, resulting in extremely dry periods during the wet season (Alves et al., 2005).

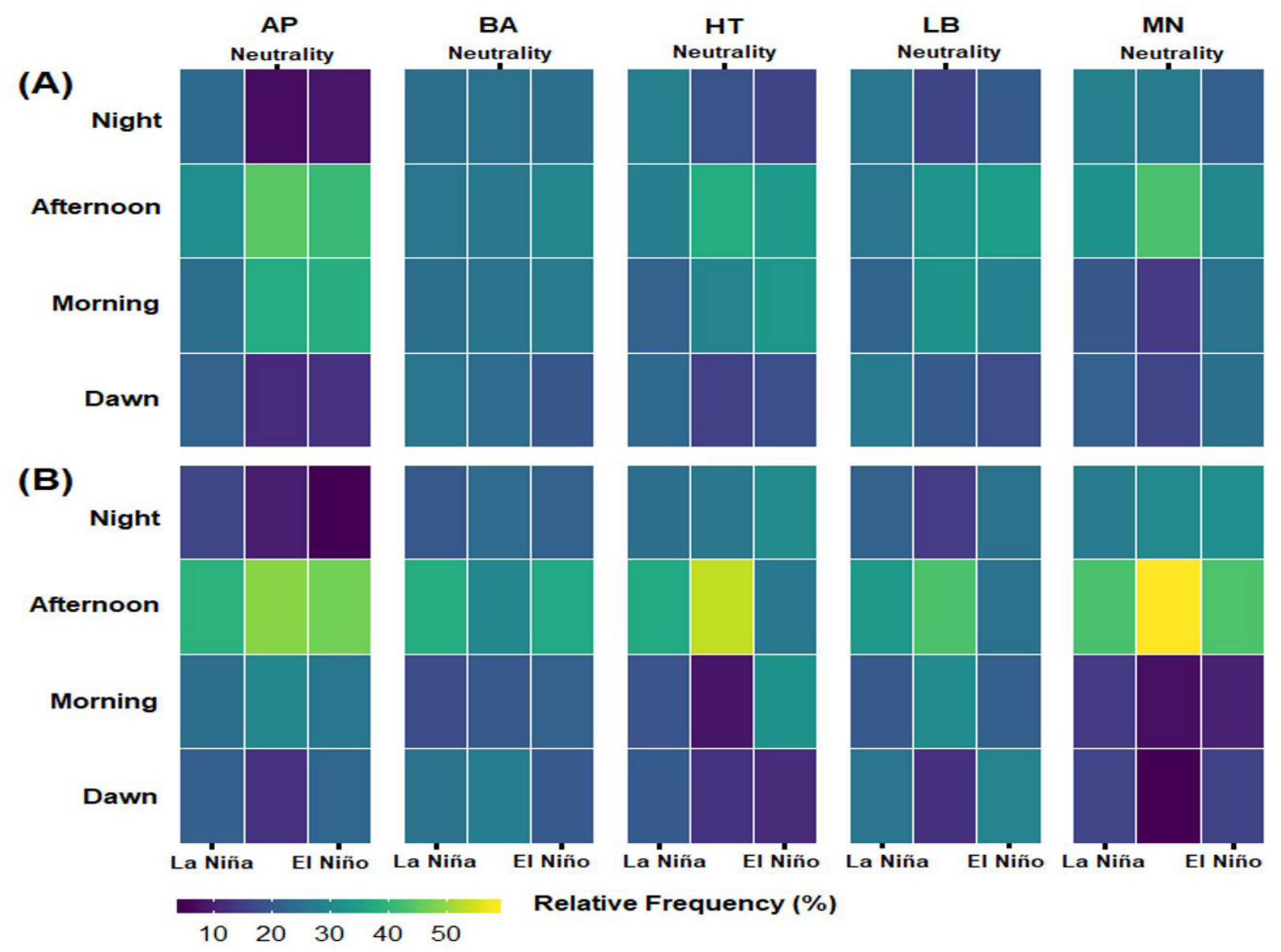

Figure 4. Relative frequency (\%) of rainfall on different periods of the day during the wet (A) and dry (B) season in the La Niña (January 1st, 2000 to December 31st, 2000), Neutrality (January 1st, 2013 to December 31st, 2013) and El Niño (January 1 st, 2015 to December 31st, 2015) in Apuí (AP), Boca do Acre (BA), Humaitá (HT), Lábrea (LB) and Manicoré (MN).

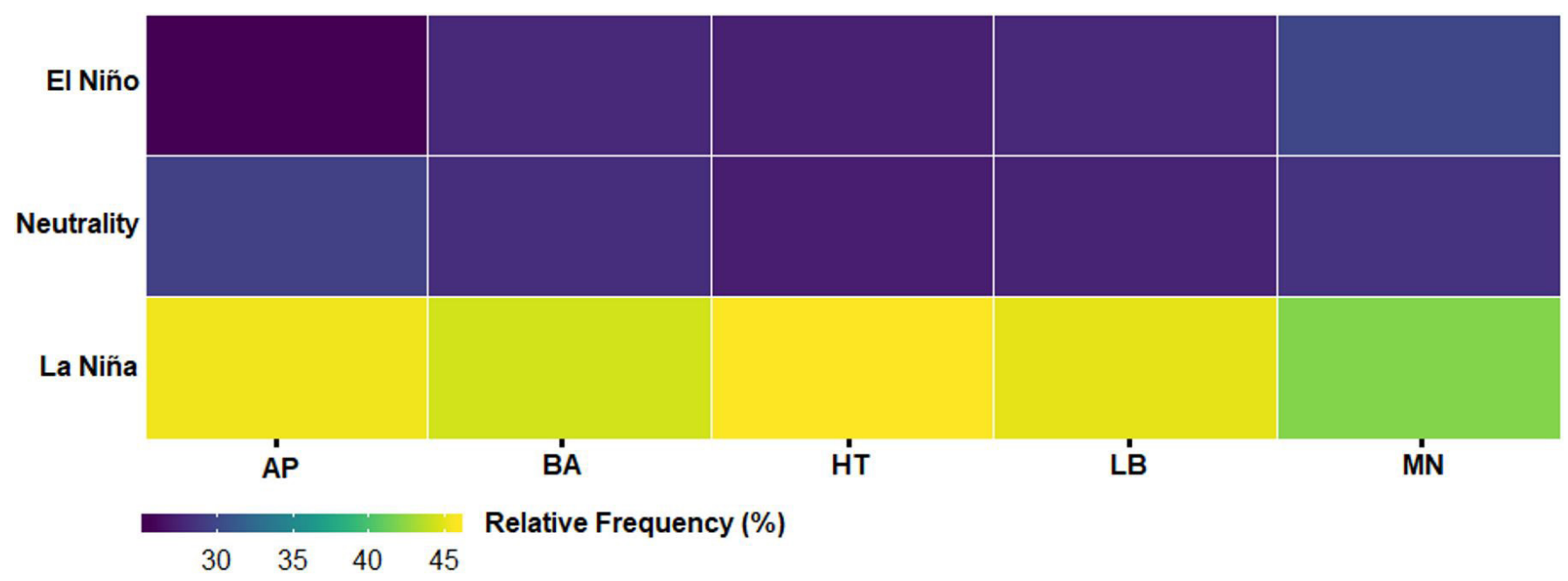

Figure 5. Relative frequency (\%) of rainfall during events of La Niña (January 1st, 2000 to December 31st, 2000), Neutrality (January 1st, 2013 to December 31st, 2013) and El Niño (January 1st, 2015 to December 31st, 2015) in Apuí (AP), Boca do Acre (BA), Humaitá (HT), Labrea (LB) and Manicoré (MN). 


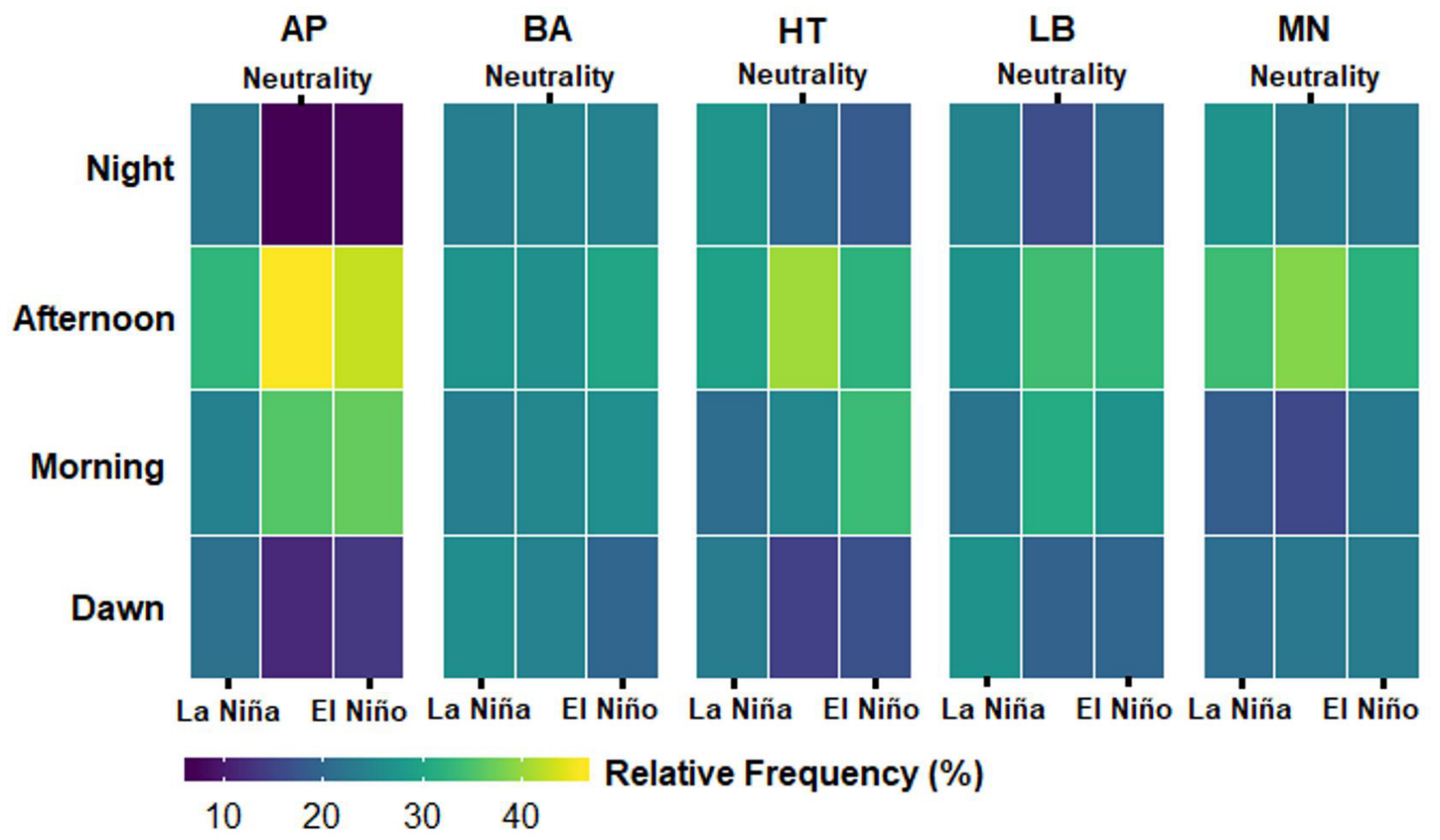

Figure 6. Relative frequency (\%) of rainfall on different periods of the day in the La Niña (January 1st, 2000 to December 31st, 2000), Neutrality (January 1st, 2013 to December 31st, 2013) and El Niño (January 1st, 2015 to December 31st, 2015) in Apuí (AP), Boca do Acre (BA), Humaitá (HT), Lábrea (LB) and Manicoré (MN).

\section{CONCLUSION}

Rainfall in AP, BA, LB, HT and MN throughout the entire period was more frequent in the afternoon and less frequent at dawn and morning. The RF during event of La Niña was higher than El Niño in all localities, but the RF during the Neutral year in AP and BA was higher than El Niño year and had no difference in $\mathrm{LB}, \mathrm{MN}$ and $\mathrm{HT}$.

\section{ACKNOWLEDGEMENTS}

The research was supported in part by Universidade Federal do Amazonas (UFAM), Universidade Federal de Mato Grosso (UFMT), Programa de Pós-Graduação em Física Ambiental (PPGFA/IF/UFMT), Instituto Federal de Mato Grosso (IFMT), Coordenação de Aperfeiçoamento de Pessoal de Nível Superior (CAPES), Conselho Nacional de Desenvolvimento Científico e Tecnológico (CNPq, code numbers 310879/2017-5 and 305761/2018-8; Edital Universal 01/2016, code number 407463/2016-0) and Fundação de Amparo à Pesquisa do Estado de Mato Grosso (FAPEMAT PRONEM 2014, code number 561397/2014). The authors thank the National Aeronautics and Space Administration (NASA), and the National Weather Service (NOAA) to data availability.

\section{REFERENCES}

Alves, J. M. B., Ferreira, F. F., \& Campos, J. N. B. (2005). Movimento vertical e índices atmosféricos associados às células de Hadley e Walker em anos de contrastes climáticos: relação com chuvas do
Setor Norte do Nordeste do Brasil (SNNEB). Revista Brasileira de Meteorologia, 20, 15-36.

Amanajás, J. C., \& Braga, C. C. (2012). Padrões espaço-temporal pluviométricos na Amazônia Oriental utilizando análise multivariada. Revista Brasileira de Meteorologia, 27(4), 423-434. http://dx.doi. org/10.1590/S0102-77862012000400006.

Angelis, C. F., McGregor, G. R., \& Kidd, C. (2004). Diurnal cycle of rainfall over the Brazilian Amazon. Climate Research, 26, 139149. http://dx.doi.org/10.3354/cr026139.

Artaxo, P., Rizzo, L. V., Paixão, M. A., Lucca, S., Oliveira, P., Lara, L. L., Wiedemann, K. R., Andreae, M. O., Holben, B., Schafer, J., Correia, L. A., \& Pauliquevis, T. M. (2009). Partículas de aerossóis na Amazônia: composição, papel no balanço de radiação, formação de nuvem e ciclos de nutrientes (Geophysical Monograph Series, No. 186, pp. 233-250). Washington: American Geophysical Union.

Brown, V. M., Black, A. W., \& Keim, B. D. (2018, 30 November). Hourly rainfall climatology of Louisiana. Theoretical and Applied Climatology.

Burauskaite-Harju, A., Grimvall, A., Achberger, C., Walther, A., \& Chen, D. (2012). Characterizing and visualizing spatiotemporal patterns in hourly precipitation records. Theoretical and Applied Climatology, 109(3-4), 333-343. http://dx.doi.org/10.1007/ s00704-011-0574-x. 
Carvalho, L. M. V., Silva, A. E., Liebmann, C. J. B., Dias, P. L. S., \& Rocha, H. R. (2012). Moisture transport and intraseasonal variability in the South America monsoon system. Climate Dynamics, 36(910), 1865-1880. http://dx.doi.org/10.1007/s00382-010-0806-2.

Centro de Previsão de Tempo e Estudos Climáticos - CPTEC. (2015). Retrieved in 2019, April 14, from https://www.cptec.inpe.br/

Costa, A. C. L., Rodrigues, H. J. B., Silva Junior, J. A., Nunes, L. R. C., Moraes, B. C., Costa, A. C., Cunha, A. C., Meir, P. W., \& Malhi, Y. S. (2018). Variabilidade horária, diária e sazonal da frequência e intensidade de precipitação em uma floresta tropical chuvosa na Amazônia brasileira. Revista Brasileira de Geografia Física, 11(4), 1290-1302. http://dx.doi.org/10.26848/rbgf.v11.4.p1290-1302.

Cutrim, E. M. C., Martin, D. W., Butzow, D. G., Silva, I. M., \& Yulaeva, E. (2000). Pilot analysis of hourly rainfall in Central and Eastern Amazonia. Journal of Climate, 13(7), 1326-1334. http:/ / dx.doi.org/10.1175/1520-0442(2000)013<1326:PAOHRI>2.0.CO;2.

Debortoli, N., Dubreuil, V., Funatsu, B., Delahaye, F., Henke, C., Rodrigues-Filho, S., Saito, C., \& Fetter, R. (2015). Rainfall patterns in the Southern Amazon: a chronological perspective (19712010). Climatic Change, 132, 251-264. http://dx.doi.org/10.1007/ s10584-015-1415-1.

Fearnside, P. M. (2005). Deforestation in Brazilian Amazonia: history, rates, and consequences. Conservation Biology, 19(3), 680-688. http://dx.doi.org/10.1111/j.1523-1739.2005.00697.x.

Ferreira, D. B. S., Souza, E. B., \& Moraes, B. C. (2013). Ciclo horário da precipitação no leste da Amazônia durante o período chuvoso. Revista Brasileira de Climatologia, 13, 74-86.

Franca, R. R., \& Mendonça, F. A. (2016). A pluviosidade da Amazônia Meridional: variabilidade e teleconexões extra-regionais. Confins, 29, 1.

Funatsu, B. M., Dubreuil, V., Claud, C., Arvor, D., \& Gan, M. A. (2012). Convective activity in Mato Grosso state (Brazil) from microwave satellite observations: comparisons between AMSU and TRMM data sets. Journal of Geophysical Research, 117(D16), 1-16. http://dx.doi.org/10.1029/2011JD017259.

Instituto Nacional de Meteorologia - INMET. (2009). Normais climatológicas do Brasil 1961-1990. Brasília: INMET.

Jacques-Coper, M., \& Garreaud, R. D. (2015). Characterization of the 1970s climate shift in South America. International Journal of Climatology, 35(8), 2164-2179. http://dx.doi.org/10.1002/joc.4120.

Joshi, S., Garbrecht, J., \& Brown, D. (2019). Observed spatiotemporal trends in intense precipitation events across United States: applications for stochastic weather generation. Climate, 7(3), 36. http://dx.doi.org/10.3390/cli7030036.

Li, W., Zhang, P., Ye, J., Li, L., \& Baker, P. A. (2011). Impact of two different types of El Nino events on the Amazon climate and ecosystem productivity. Journal of Plant Ecology, 4(1-2), 91-99. http://dx.doi.org/10.1093/jpe/rtq039.

Limberger, L., \& Silva, M. E. S. (2016). Precipitação na bacia amazônica e sua associação à variabilidade da temperatura da superfície dos oceanos Pacífico e Atlântico: uma revisão. Geousp: espaço e tempo, 20(3), 657-675. http://dx.doi.org/10.11606/issn.21790892.geousp.2016.105393

Loureiro, R. S., Saraiva, J. M., Saraiva, I., Senna, R. C., \& Fredó, A. S. (2014). Estudo dos eventos extremos de precipitação ocorridos em 2009 no estado do Pará. Revista Brasileira de Meteorologia, 29(spe), 83-94. http://dx.doi.org/10.1590/0102-778620130054.

Marengo, J. A., \& Espinoza, J. C. (2016). Secas sazonais extremas e inundações na Amazônia: causas, tendências e impactos. International Journal of Climatology, 36(3), 1033-1050. http:/ / dx.doi. org/10.1002/joc. 4420 .

Marengo, J., \& Nobre, C. (2009). Clima da região amazônica. In I. F. A. Cavalcanti (Ed.), Tempo e clima do Brasil (pp. 198-212). São Paulo: Oficina de Textos.

Martins, P. A. S. (2019). Balanço bídrico e classificação climática para a mesorregião sul do Amazonas (Dissertação de mestrado). Universidade Federal do Amazonas, Humaitá.

Martins, P. A. S., Querino, C. A. S., Querino, J. K. A. S., Moura, A. R. M., \& Souza, S. A. S. (2018). Variabilidade da precipitação e da temperatura do ar no Sul do Amazonas. In Anais do $V$ Seminário Internacional em Ciências do Ambiente e Sustentabilidade na Amazônia (SICASA). Manaus: UFAM.

Mei, R., \& Wang, G. L. (2012). Summer land-atmosphere coupling strength in the United States: comparison among observations, reanalysis data and numerical models. Journal of Hydrometeorology, 13(3), 1010-1022. http://dx.doi.org/10.1175/JHM-D-11-075.1.

National Aeronautics and Space Administration - NASA. (2019). Retrieved in 2019, April 8, from https:/ /giovanni.gsfc.nasa.gov/

National Weather Service - NOAA. Climate Prediction Center. (2019). Cold \& warm episodes by season. Maryland: NOAA. Retrieved in 2019, April 8, from https:/ / origin.cpc.ncep.noaa.gov/products/ analysis_monitoring/ensostuff/ONI_v5.php

Pedreira Junior, A. L., Querino, C. A. S., Querino, J. K. A. S., Santos, L. O. F., Moura, A. R. M., Machado, N. G., \& Biudes, M. S. (2018). Variabilidade horária e intensidade sazonal da precipitação no município de Humaitá - AM. Revista Brasileira de Climatologia, 22, 463-475. http://dx.doi.org/10.5380/abclima.v22i0.58089.

Rao, J., \& Ren, R. (2017). Parallel comparison of the 1982/83, 1997/98 and 2015/16 super El Niños and their effects on the extratropical stratosphere. Advances in Atmospheric Sciences, 34(9), 1121-1133. http://dx.doi.org/10.1007/s00376-017-6260-x.

Rodell, M., Houser, P. R., Jambor, U., Gottschalck, J., Mitchell, K., Meng, C., Arsenault, K., Cosgrove, B., Radakovich, J., Bosilovich, 
M., Entin, J., Walker, J. P., Lohmann, D., \& Toll, D. (2004). The global land data assimilation system. Bulletin of the American Meteorological Society, 85(3), 381-394. http://dx.doi.org/10.1175/ BAMS-85-3-381.

Rolim, P., Santos, D. M., \& Rocha, E. J. P. (2006). Variabilidade da precipitação na Amazônia: implicações socioeconômicas. In Anais do XIV Congresso Brasileiro de Meteorologia. Rio de Janeiro: SBMET.

Ronchail, J. G., Cochonneau, M., Molinier, J. L., Guyot, A. G., Miranda, C., Guimarães, V., \& Oliveira, E. (2002). Interannual rainfall variability in the Amazon basin and sea-surface temperatures in the equatorial Pacific and tropical Atlantic Oceans. International Journal of Climatology, 22(13), 1663-1686. http://dx.doi.org/10.1002/joc.815.

Santos Neto, L. A., Maniesi, V., Silva, M. J. G., Querino, C. A. S., Lucas, E. W. M., Braga, A. P., \& Ataíde, K. R. P. (2014). Distribuição horária da precipitação em Porto Velho-RO no período de 19982013. Revista Brasileira de Climatologia, 14(10), 213-228.

Santos, L. O. F., Querino, C. A. S., Querino, J. K. A. S., Pedreira Junior, A. L., Moura, A. R. M., Machado, N. G., \& Biudes, M. S. (2019). Validation of rainfall data estimated by GPM satellite on Southern Amazon region. Revista Ambiente \& Água, 14(1), e22499. http://dx.doi.org/10.4136/ambi-agua.2249.

Satyamurty, P., Wanzeler, C. P. C., \& Manzi, A. O. (2012). Moisture source for the Amazon Basin: a study of contrasting years. Theoretical and Applied Climatology, 111(1-2), 195-209. http://dx.doi. org/10.1007/s00704-012-0637-7.

Shimizu, M. H., Ambrizzi, T., \& Liebmann, B. (2017). Extreme precipitation events and their relationship with ENSO and MJO phases over northern South America. International Journal of Climatology, 37(6), 2977-2989. http://dx.doi.org/10.1002/joc.4893.

Souza, E. B., \& Ambrizzi, T. (2002). Enso impacts on the south American rainfall during 1980s: hadley and walker circulations. Atmosphere, 15, 105-120.

Souza, E. B., Kayano, M. T., \& Ambrizzi, T. (2005). Intraseasonal and submonthly variability over the eastern Amazon and Northeast Brazil during the autumn rainy season. Theoretical and Applied Climatology, 81(3-4), 177-191. http://dx.doi.org/10.1007/s00704004-0081-4.

Spiegel, M. R. (1972). Estatística. São Paulo: McGraw-Hill do Brasil.
Sun, X., Renard, B., Thyer, M., Westra, S., \& Lang, M. (2015). A global analysis of the asymmetric effect of ENSO on extreme precipitation. Journal of Hydrology, 530, 51-65. http://dx.doi. org/10.1016/j.jhydrol.2015.09.016.

Tanaka, L. M., Satyamurty, P., \& Machado, L. A. (2014). Diurnal variation of precipitation in central Amazon basin. International Journal of Climatology, 34(13), 3574-3584. http://dx.doi.org/10.1002/ joc.3929.

Tedeschi, R. G., Grimm, A. M., \& Cavalcanti, I. F. (2015). Influence of Central and East ENSO on extreme events of precipitation in South America during austral spring and summer. International Journal of Climatology, 35(8), 2045-2064. http://dx.doi.org/10.1002/ joc.4106.

Wang, C. A. (2002). Atmospheric circulation cells associated with the el niño-southern oscilation. Journal of Climate, 13, 3969-3993.

Westra, S., Alexander, L. V., \& Zwiers, F. W. (2013). Global increasing trends in annual maximum daily precipitation. Journal of Climate, 26(11), 3903-3918. http://dx.doi.org/10.1175/JCLI-D-12-00502.1.

\section{Authors contributions}

Altemar Lopes Pedreira Junior: Responsible for data acquisition, methodology and analysis, as well as writing and formatting the paper.

Carlos Alexandre Santos Querino: Guided in the definition of objectives, methodology for evaluating precipitation data and participated in the review and development of the paper.

Marcelo Sacardi Biudes: Guided in the definition of objectives, methodology for evaluating precipitation data and participated in the general review of the paper.

Nadja Gomes Machado: Guided the definition of the methodology, translated the paper and participated in the review of the paper.

Luiz Octavio Fabricio dos Santos: Contributed to data analysis and paper review.

Israel Oliveira Ivo: Contributed to data analysis and paper review. 